\title{
CLIMATIC SUITABILITY FOR Eucalyptus cloeziana CULTIVATION IN FOUR BRAZILIAN STATES
}

\author{
Bruno Oliveira Lafetá ${ }^{1 *}$, Reynaldo Campos Santana ${ }^{2}$, Tamires Mousslech Andrade Penido ${ }^{2}$, Evandro Luiz \\ Mendonça Machado², Diego dos Santos Vieira² \\ $1 *$ Federal Institute of Education, Science and Technology of Minas Gerais, Department of Forestry, São João Evangelista, Minas Gerais, \\ Brazil - bruno.lafeta@ifmg.edu.br \\ ${ }^{2}$ Federal University of Vales do Jequitinhonha e Mucuri, Diamantina, Minas Gerais, Brazil - silviculturaufvjm@ yahoo.com.br, \\ penidotma@gmail.com, machadoelm@gmail.com, diegovieir4@gmail.com
}

Received for publication: 04/02/2017 - Accepted for publication: 08/01/2018

\begin{abstract}
This study aimed to identify potentially climatic zones for Eucalyptus cloeziana cultivation in four Brazilian states - Bahia - BA, Mato Grosso do Sul - MS, Minas Gerais - MG and São Paulo - SP. 490 records of this species were obtained in Australia. The current prediction for habitat suitability distribution was based on climatic conditions recorded between 1960 and 1990. For 2050's future projections, four scenarios were used: $\mathrm{RCP} 2.6 \mathrm{~W} / \mathrm{m}^{2}, \mathrm{RCP} 4.5 \mathrm{~W} / \mathrm{m}^{2}, \mathrm{RCP} 6.0 \mathrm{~W} / \mathrm{m}^{2}$ and $\mathrm{RCP} 8.5 \mathrm{~W} / \mathrm{m}^{2}$. MaxEnt was used for modeling, and only climatic information was used as a predictor variable. The modeling was robust and presented high values for the Area Under the Curve (AUC) (> 0.95). Annual precipitation and isothermality were the variables that contributed the most to the models' quality. We concluded that the Brazilian mesoregions of Itapetininga (SP), Litoral Sul Paulista (SP) and Zona da Mata (MG) had the most suitable climatic sites for E. cloeziana cultivation. Climate changes may restrict the distribution of suitable areas for E. cloeziana cultivation. The negative effect of global warming was more prominent in MG.

Keywords: Forest stands, climate changes, future projection, zoning.
\end{abstract}

\section{Resumo}

Adequabilidade climática para o cultivo de Eucalyptus cloeziana em quatro estados do Brasil. O objetivo do presente trabalho foi identificar zonas com potencial climático para o cultivo de Eucalyptus cloeziana em quatro estados brasileiros (Bahia - BA, Mato Grosso do Sul - MS, Minas Gerais - MG e São Paulo - SP). Foram obtidos 490 registros dessa espécie na Austrália. A predição atual da distribuição de adequabilidade de habitat se baseou em condições climatéricas registradas entre 1960 e 1990. Para as projeções futuras de 2050, foram utilizados quatro cenários: RCP $2.6 \mathrm{~W} / \mathrm{m}^{2}$, RCP $4.5 \mathrm{~W} / \mathrm{m}^{2}$, RCP $6.0 \mathrm{~W} / \mathrm{m}^{2}$ e RCP $8.5 \mathrm{~W} / \mathrm{m}^{2}$. O MaxEnt foi usado na modelagem, empregando apenas informações climáticas como variáveis preditoras. A modelagem foi robusta e apresentou elevados valores de AUC $(>0,95)$. A precipitação anual e isotermalidade foram as variáveis que mais contribuíram para a qualidade dos modelos. Concluiu-se que as mesorregiões brasileiras de Itapetininga (SP), Litoral Sul Paulista (SP) e Zona da Mata (MG) apresentaram os sítios mais adequados climaticamente para o cultivo de E. cloeziana. As mudanças climáticas podem restringir a distribuição de zonas adequadas para o cultivo de E. cloeziana. O efeito negativo do aquecimento global foi mais proeminente em MG.

Palavras-chave: Povoamentos florestais, mudanças climáticas, projeção futura, zoneamento.

\section{INTRODUCTION}

The growing demand for energy, associated to the awareness in reducing emissions of Greenhouse Gases (GHG), has been promoting the use of vegetal biomass as an energy source (JONKER et al., 2016). Even-aged stands installation is an alternative to minimize the pressure over native vegetation. The Eucalyptus (Myrtaceae) genus was introduced in Brazil due to its rapid growth, high productivity, large phenotypic plasticity and economic relevance. Historically, Eucalyptus cloeziana is one of the most cultivated species for energy, sawmill, civil constructions, posts, and railway ties purposes (TRUGUILHO et al., 2015). This species has tree size, high fixed carbon content, good density, stem straightness and durable brownish-yellow wood (SANTOS et al., 2002).

The fifth report from the Intergovernmental Panel on Climate Change (IPCC) confirmed the anthropogenic influence on global warming and described four future scenarios of GHG concentrations. The scenarios simulate climate warming in relation to the total radioactive force in 2100 (MASUI et al., 2011; RIAHI et al., 2011; THOMSON et al., 2011; van VUUREN et al., 2011; van VUUREN et al., 2014). Modeling these scenarios aims to improve the understanding of ecological patterns and how they can be modified.

Species Distribution Models (SDM) are statistical techniques that describe how a population can be distributed in space and time, and they usually describe the fundamental niche of species (VESSELLA; SCHIRONE, 2013). The

FLORESTA, Curitiba, PR, v. 48, n. 1, p. 77-86, jan./mar. 2018.

Lafetá. B. O. et al.

ISSN eletrônico 1982-4688

DOI: $10.5380 /$ rf.v48 i 150496 
application of SDM enables the characterization of a population's probable environmental needs, even in non-sampled areas. Spatial modeling of habitat suitability has already been successfully performed in ecology, paleobiology, epidemiology, and planning of protected areas (SVENNING et al., 2011; VESSELLA; SCHIRONE, 2013; FERERSÁNCHEZ; RODRÍGUEZ-ESTRELLA, 2016).

One alternative for modeling niches and performing current projections for different future scenarios is the maximum entropy software (MaxEnt)(PHILLIPS et al., 2006). MaxEnt uses georeferenced records and combines species distribution with environmental information rasters (VESSELLA; SCHIRONE, 2013). It also enables the explicitly determination of spatial distribution patterns and their responses to environmental changes. It is a popular and flexible tool and has an easy-to-use interface (FERRER-SÁNCHEZ; RODRÍGUEZESTRELLA, 2016). Its algorithms have demonstrated the best or one of the best predictive approaches, capable of solving complex interactions (PHILLIPS et al., 2006; ELITH et al., 2011).

The Brazilian territory extension is of $8.514 .876 \mathrm{~km}^{2}$, and the climatic heterogeneity increases in its interior (INMET, 2016). Models that predict habitat adequacy in large-scale are efficient and practical for silvicultural decisions and forest management. Based on the need to assess current and future distribution of zones suitable for E. cloeziana cultivation, the following hypotheses were tested: i) do the states of Mato Grosso do Sul, Minas Gerais, São Paulo and Bahia present climatic suitability for E. cloeziana cultivation? ii) is the future tendency likely to remain the same? Therefore, the present study aimed to identify potentially climatic areas for E. cloeziana cultivation in four Brazilian states.

\section{MATERIAL AND METHODS}

\section{Occurrence records}

A survey regarding the distribution of E. cloeziana was conducted at the Australian Virtual Herbarium. 490 georeferenced records from the states of Queensland, New South Wales, Victoria, and the Australian capital territory were used. Most records were concentrated on Queensland, on the quadrant formed between the latitude coordinates $10 \mathrm{~S}$ and $20 \mathrm{~S}$ and the longitude coordinates $140 \mathrm{E}$ and $155 \mathrm{E}$.

Australian and Brazilian administrative boundaries (Central-West region: Mato Grosso do Sul, Southeast: Minas Gerais and São Paulo, and Northeast: Bahia) derived from the Global Administrative Areas database, version 2.8. These four states have the largest area cultivated with Eucalyptus genus in Brazil (ABRAF, 2013). The geographic reference coordinate system was datum WGS84. ESRI ArcMap 10.3.1 and Excel ${ }^{\circledR}$ softwares were used for spatial analysis.

\section{Bioclimatic variables}

Current and future climate information was obtained from Worldclim, version 1.4, with spatial resolution of around $1 \mathrm{Km}^{2}$ (equivalent to 30" pixel resolution). This information refers to monthly, quarterly and annual variables for temperature and precipitation, and it has great biological relevance for the distribution of plant species (KUMAR; STOHLGREN, 2009). Current data were based on climatic conditions recorded between 1960 and 1990. This information was generated by interpolation of observations from terrestrial meteorological stations, using latitude, longitude and altitude as predictor variables.

For 2050's future projections (average of 2041 - 2060), four Representative Concentration Pathways (RCP) scenarios were used, based on the MIROC 5 (Model for Interdisciplinary Research on Climate) climate model: two optimists (RCP 2.6 and RCP 4.5) and two pessimists (RCP 6.0 and RCP 8.5). RCP 2.6 assumes a GHG saturation peak around 2020 and a radioactive force of $2.6 \mathrm{~W} / \mathrm{m}^{2}$ in 2100 (van VUUREN et al., 2011). On one hand, RCPs 4.5 and 6.0 consider saturation peaks in 2040 and 2080, respectively (THOMSON, 2011; MASUI et al., 2011). The radioactive force of these two scenarios tends to stabilize by the end of the 21st century: the first one with $4.5 \mathrm{~W} / \mathrm{m}^{2}$ and the second one with $6.0 \mathrm{~W} / \mathrm{m}^{2}$ (van VUUREN et al., 2014). On the other hand, RCP 8.5 considers increasing GHG emissions and $8.5 \mathrm{~W} / \mathrm{m}^{2}$ till 2100 (RIAHI et al., 2011).

All 19 bioclimatic variables provided by Worldclim were submitted to Pearson correlation analysis (r). Values of $r \geq|0.80|$ were adopted as limit for excluding highly correlated variables, as suggested by Lahue et al. (2016). This procedure aims to minimize multicollinearity and overtfitting, which could lead to loss of the model's predictor precision (RÖDDER et al., 2009; LAHUE et al., 2016). We selected nine variables in order to evaluate the spatial distribution of climatic suitability for E. cloeziana habitat (Table 1). The environmental variables were the same for both present and future projections, and they were designed as raster layers and converted to ASCII (American Standard Code for Information Interchange) format for subsequent analyses. 
Table 1. Bioclimatic variables considered as relevant for the spatial distribution model of habitat suitability for E. cloeziana.

Tabela 1. Variáveis bioclimáticas consideradas relevantes para o modelo de distribuição espacial da adequabilidade de habitat para E. cloeziana.

\begin{tabular}{lcc}
\hline \multicolumn{1}{c}{ Environmental Variables } & Codes & Units \\
\hline Annual average temperature & Bio 1 & ${ }^{\circ} \mathrm{C}$ \\
Average variation of daytime temperature & Bio 2 & ${ }^{\circ} \mathrm{C}$ \\
Isothermality & Bio 3 & Dimensionless \\
Maximum temperature in the hottest month & Bio 5 & ${ }^{\circ} \mathrm{C}$ \\
Minimum temperature in the coldest month & Bio 6 & ${ }^{\circ} \mathrm{C}$ \\
Average temperature in the driest quarter & Bio 9 & ${ }^{\circ} \mathrm{C}$ \\
Annual rainfall & Bio 12 & $\mathrm{mm}$ \\
Rainfall seasonality (coefficient of variation) & Bio 15 & Dimensionless \\
Rainfall in the driest quarter & Bio 17 & mm \\
\hline Bio 3 $=[$ Bio 2/(Bio 5-Bio 6) $] 100$. & &
\end{tabular}

\section{Modeling and assessment method}

MaxEnt (version 3.3.3) was used for calculations and mapping. MaxEnt is an automatic learning technique that implements algorithms in order to perform inferences and predictions regarding species' geographical distribution (RÖDDER et al., 2009). It only requires species presence data and continuous or categorical environmental variables to measure the theoretical entropy (PHILLIPS et al., 2006). The standard logistic output of MaxEnt provides estimates of the spatial distribution probability of habitat suitability, ranging from 0 (least fit) to 1 (greater relative adaptability).

Each model was the resulting mean of 15 replicates applied to the subsample replication function. $75 \%$ of the records were randomly defined as training set and the remainder (25\%) as test set. It is worth emphasizing that the training stage consists of the parameterization of the model and that the test stage evaluates the accuracy of the model. The maximum iterations were 20000. The standard MaxEnt values were used for the convergence threshold $\left(10^{-5}\right.$, in which model training is discontinued): regularization multiplier $(1,0)$, maximum number of background points (10000 randomly distributed points), and standard prevalence (0.5). The Minimum Training Presence threshold was adopted as a cutoff point for suitability.

The quality evaluation of the adjusted models was performed by calculating the Area Under the Curve (AUC), which is obtained from the integration of the Receiver Operating Characteristic (ROC) curve. It is worth noting that the maximum AUC value is 1.0, which indicates perfect discrimination, while values lower than 0.5 denote poor modeling performance. The Jackknife test was applied to diagnose the relative contribution of variables. Graphic analyses were performed with box plot.

\section{RESULTS}

The AUC means of the training and test stages were $0.9809 \pm 0.0015$ and $0.9729 \pm 0.0060$, respectively (Figure 1). The bioclimatic variables that most contributed to the modeling were Bio 12 and Bio 3, with a mean contribution of $47.96 \%$. It was verified that a suitable habitat (probability $\geq 0.55$ ) for E. cloeziana should present an annual precipitation greater than $650 \mathrm{~mm}$ and isothermality between 50 and 59. The largest fraction of records was verified considering the circumscribed range by this probability value. This precipitation interval had a high concentration in the Australian surveys, $91.2 \%$, and presented isothermality of $94.7 \%$.

FLORESTA, Curitiba, PR, v. 48, n. 1, p. 77-86, jan./mar. 2018

Lafetá. B. O. et al.

ISSN eletrônico 1982-4688

DOI: $10.5380 /$ rf.v48 i150496 

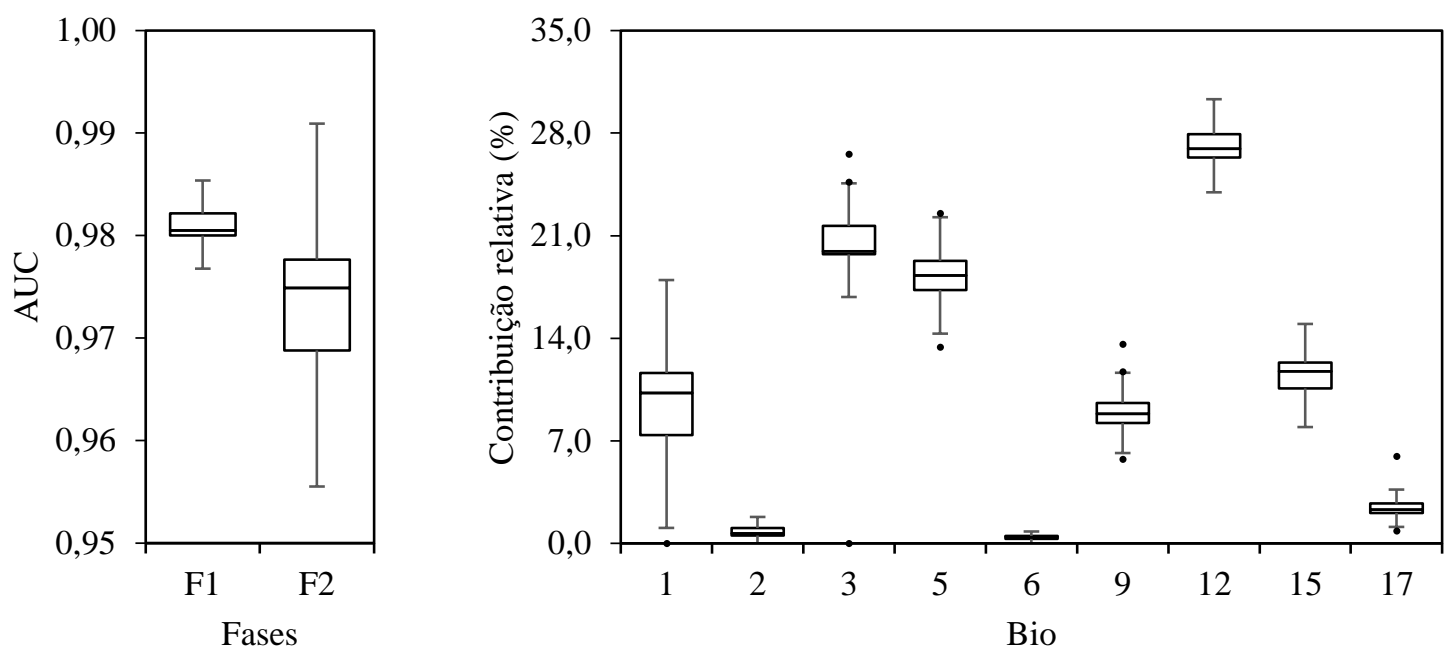

Figure 1. Variations of AUC of ROC in the training (S1) and test (S2) stages, on the left. Relative contribution of bioclimatic variables on the right.

Figura 1. Variações de AUC de ROC nas fases de treinamento (F1) e de teste $(\mathrm{F} 2)$ à esquerda. Contribuição relativa das variáveis bioclimáticas à direita.

Bio 2, Bio 6 and Bio 17 contributed little to the adjustments. Furthermore, these variables did not correlate strongly $(\mathrm{r}<|0.8|$ ) with the others selected. The AUC means of these three variables, when used alone, were 0.6866, 0.6279 and 0.8108, respectively. The presence of outliers in the relative contribution of Bio 3, Bio 5, Bio 9 and Bio 17 was verified. These discrepancies did not affect the quality of the adjustments made.

The modeling was robust and captured the variability of bioclimatic variables at the points with the presence of E. cloeziana in Australia, with high AUC values (>0.95) (Figure 2). The regions with probability> 0.20 (mean of 15 replicates), for a randomly selected location that presented adequate climatic conditions for this species, were observed in São Paulo (Itapetininga, Litoral Sul Paulista, Macro Metropolitana Paulista, Metropolitana de São Paulo e Vale do Paraíba Paulista) and Minas Gerais (Zona da Mata, Metropolitana de Belo Horizonte e Vale do Jequitinhonha). The mesoregions of Itapetininga, Southern coast of São Paulo and Zona da Mata presented sites with probabilities higher than 0.5 for habitat suitability.

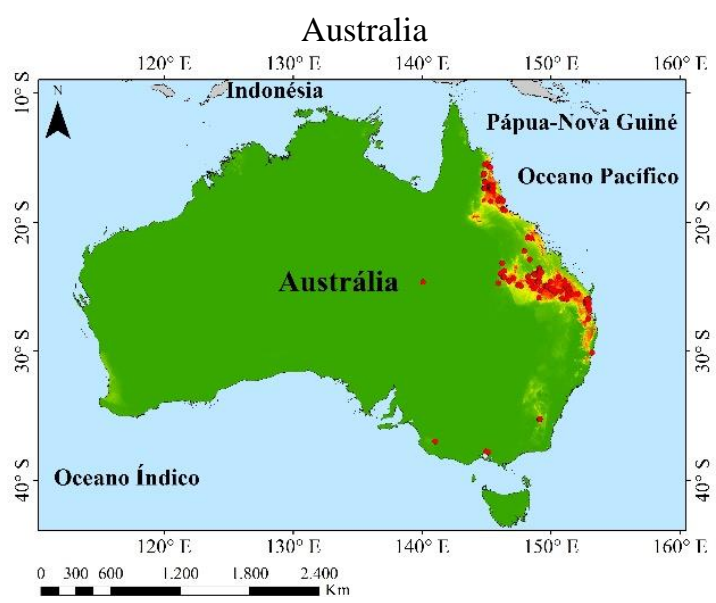

States of Brazil - Minimum

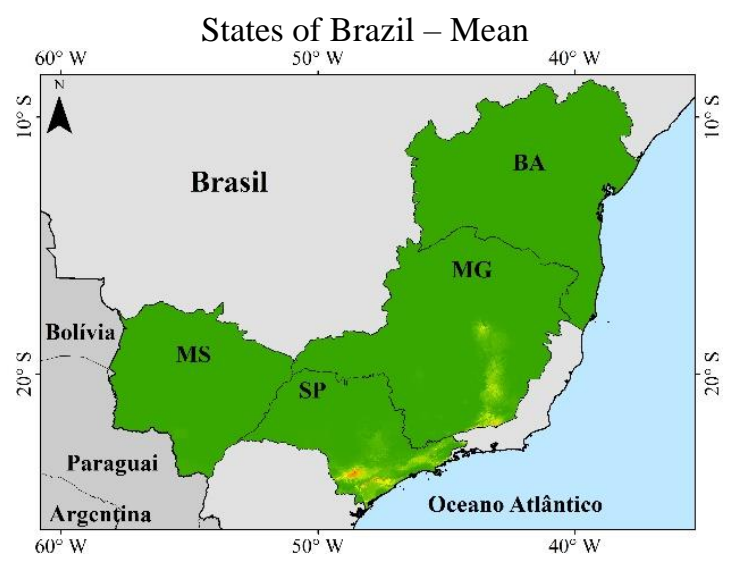

States of Brazil - Maximum 

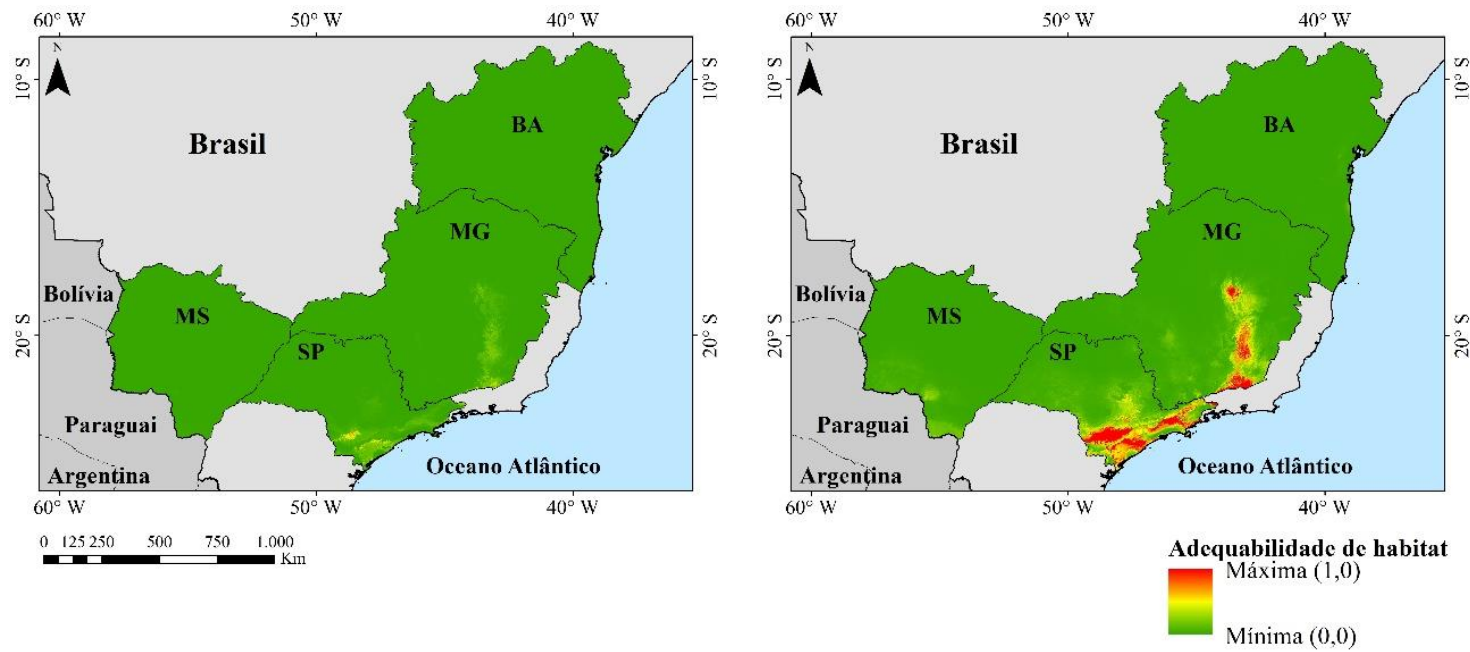

Figure 2. The current representation of habitat suitability for E. cloeziana in Australia and in four Brazilian states (Bahia - BA, Minas Gerais - MG, Mato Grosso do Sul - MS and São Paulo - SP). The mean, minimum and maximum estimates were obtained from 15 replicates.

Figura 2. Representação atual da adequabilidade de habitat para E. cloeziana na Austrália e em quatro estados do Brasil (Bahia - BA; Minas Gerais - MG; Mato Grosso do Sul - MS e São Paulo - SP). As estimativas média, mínima e máxima foram obtidas de 15 réplicas.

The future projections of the four RCP scenarios presented a decrease of the area with climatic suitability for E. cloeziana cultivation (Figure 3). The largest reduction was observed in the scenario RCP 8.5, proving its pessimistic characteristics in the estimates. It is important to emphasize that no edaphic and topographic variables were inserted in the modeling, only bioclimatic ones (Worldclim). Sites with probability $>0.1$ for habitat suitability were restricted to the lengths from $50 \mathrm{~W}$ to $40 \mathrm{~W}$.
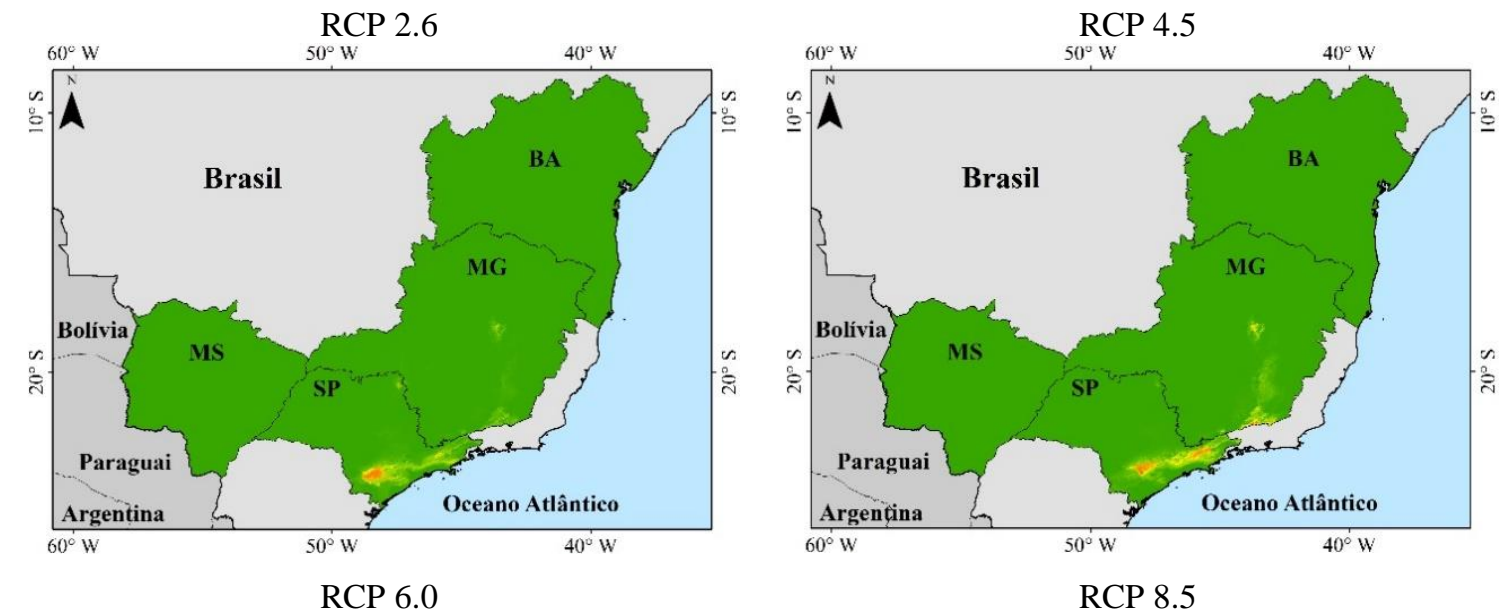

RCP 8.5

FLORESTA, Curitiba, PR, v. 48, n. 1, p. 77-86, jan./mar. 2018

Lafetá. B. O. et al.

ISSN eletrônico 1982-4688

DOI: $10.5380 /$ rf.v48 i150496 

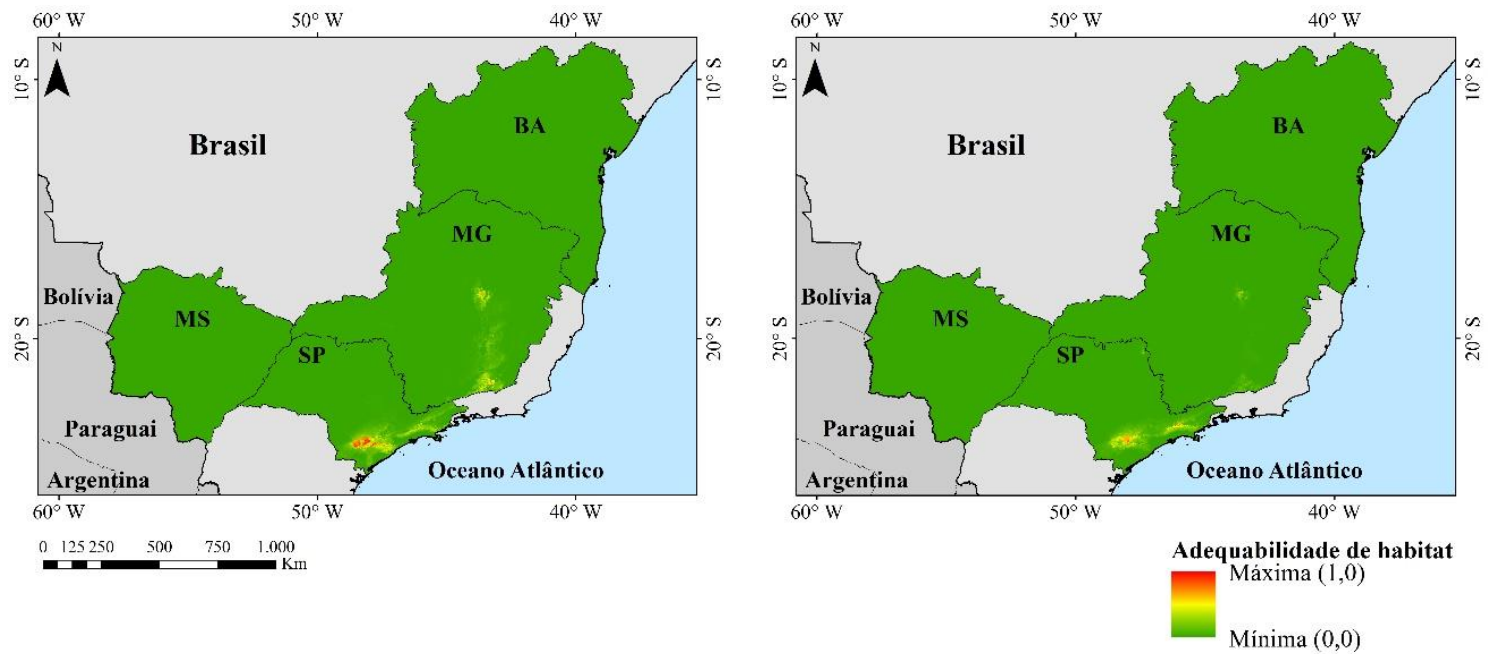

Figure 3. Future projections for the period of 2050 (mean from 2041 - 2060) with four RCP scenarios of habitat suitability for E. cloeziana in four Brazilian states (Bahia - BA, Minas Gerais - MG, Mato Grosso do Sul - MS and São Paulo - SP).

Figura 3. Projeções futuras do período de 2050 (média de 2041 - 2060) com quatro cenários RCP da adequabilidade de habitat para E. cloeziana em quatro estados do Brasil (Bahia - BA; Minas Gerais MG; Mato Grosso do Sul - MS e São Paulo - SP).

\section{DISCUSSION}

The number of E. cloeziana records was high (> 450 records), and the modeling of the climate distribution suitability to its habitat provided reliable estimates. The spatial resolution $\left(1 \mathrm{~km}^{2}\right)$ and the predictors selected for the training stage may have favored the performance of the models. It is worth noting that few records and low spatial precision are obstacles to the establishment of distribution patterns (FERRER-SÁNCHEZ; RODRÍGUEZESTRELLA, 2016).

The AUC was close to the maximum value (Figure 1), which was an indicative of excellent fit according to the criteria described in Vessella and Schirone (2013) and Jiang et al.(2014). The highest mean of AUC for the training stage and the lowest mean for the test stage did not characterize overfitting. The low standard deviation of this statistic implied a greater uniformity among the replicates. Despite the greater variability of AUC in the test stage, their values were higher than 0.95 . In addition, the number of iterations was relatively low (1756 \pm 244$)$, as the modeling contemplated large administrative limits (continental scale).

The variables that contributed the most to the predictive capacity were annual precipitation (Bio 12) and isothermality (Bio 3). The direct relationship between the probability of having a suitable climate for cultivating E. cloeziana and the annual precipitation evidenced the importance of humidity for the establishment of the plant. Water availability is one of the factors that highly limit the growth of Eucalyptus (BOURNE et al., 2015).

The isothermality effect was confirmed. When used alone, isothermality demonstrated the highest AUC gain $(0.8807 \pm 0.0325)$. It is also noteworthy that humidity and temperature can interact and influence the climatic suitability of habitats (TAIZ; ZEIGER, 2004). The Vapour Pressure Deficit (VPD) is an example of this interaction, which decreases the atmospherical water potential and restricts photosynthesis. Thus, a greater amount of water in the form of vapour is maintained in the atmosphere at high air temperatures (BOURNE et al., 2015).

The selected variables did not limit the performance of this modelling, thus providing an ample mapping and the ability to capture the environmental preferences of E. cloeziana in Australia. An overlap between the presence records and the environmental gradient was verified. This species revealed to have a climatic specificity, demanding the definition of areas with a suitable climate for its cultivation. Such specificity probably resulted from a strong phylogeographic structure of the species in its country of origin (D'AMEN et al., 2013).

The weather conditions at the recording sites in Australia (isothermality of $53.8 \pm 3.1$, average annual precipitation and temperature of $1035 \pm 376 \mathrm{~mm}$ and $20.5 \pm 1.9^{\circ} \mathrm{C}$ ) were similar to those of climatic suitability found in Brazil (probability $\geq 0.55$ ) for E. cloeziana (Worldclim; INMET, 2016). The current prediction results in Brazil were consistent with schematic ecological zoning for E. cloeziana as described by Golfari et al. (1978). The small differences found in this study may be related to the choice of predictor variables, climatic changes and/or the new records that were subsequent to the analysis performed by the authors mentioned. Changes in patterns of 
habitat distribution may occur when resources for the establishment of the plant are limited (FERRER-SÁNCHEZ; RODRÍGUEZ-ESTRELLA, 2016).

The climate restriction was higher in the states of Mato Grosso do Sul and Bahia. It is worth emphasizing that the modelling is by no means immune to making mistakes (FERRER-SÁNCHEZ; RODRÍGUEZESTRELLA, 2016) and may, in some cases, fail to classify potential areas for habitat or yet define zones as appropriate when they are actually not. Thus, it is important to consider that several factors, such as geographic barriers and anthropic activities, can influence the actual distributions. Moreover, niche changes may occur when exotic species settle in a new area and may occupy climatically different regions from those from which they originate (SILVA et al., 2014).

According to future projections, climatic changes will influence the distribution of habitat suitability of E. cloeziana, especially in Minas Gerais and in São Paulo. The RCP scenarios generated different patterns of distribution among themselves. The mesoregions of Itapetininga (SP), Macro Metropolitana Paulista (SP), Vale do Jequitinhonha (MG) and Zona da Mata (MG) maintained more suitable areas for subsequent cultivation.

A projection for the year 2050 revealed that the zones of greater climatic adequacy for E. cloeziana would be drastically reduced and that, due to this reduction, Minas Gerais would be the most impacted state. All RCP scenarios showed a narrowing of suitable areas for cultivation, of which higher yields are expected. It is fundamental to know the risks associated with climate change in order to develop silvicultural strategies that are capable of stimulating plant growth. To that end, it is recommended an analysis of a set of environmental and (if possible) biotic variables for the zoning of habitat suitability for species of commercial interest. A biotic interaction that should be taken into consideration, for instance, is the susceptibility of E. cloeziana to attacks of tent caterpillars (ZANUNCIO et al., 1998).

Understanding the spatial and temporal scale of habitat suitability is a fundamental premise to define suitable zones for planting, as well as mitigation strategies for probable climate changes. The reduction of annual precipitation and the excessive increase of temperature, especially in the hottest month, may hamper E. cloeziana cultivation. Prolonged periods of drought can also restrict production. It is interesting to choose sites that present distributed precipitation throughout the year, i. e., precipitation that does not focus on certain periods. Biotechnology and genetic improvement are options for obtaining progenies resistant to water deficit. Therefore, the inclusion of future scenarios in the environmental zoning provides subsidies to identify sites with a climatic aptitude for the cultivation of forest species, be they of slow or fast growth.

\section{CONCLUSIONS}

- The modelling with MaxEnt was efficient to estimate the probability of climate suitability for the habitat of E. cloeziana in Australia.

- The mesoregions of Itapetininga (SP), Southern Coast of São Paulo (SP) and Zona da Mata (MG) revealed to be the most climatically adequate sites for cultivating E. cloeziana.

- Climate changes may restrict the distribution of suitable areas for the cultivation of E. cloeziana. Finally, the negative effect of global warming was more prominent in Minas Gerais.

\section{REFERENCIAS}

ABRAF - ASSOCIAÇÃO BRASILEIRA DE PRODUTORES DE FLORESTAS PLANTADAS. Anuário estatístico da ABRAF 2013: Ano Base 2012. Brasília, 2013, 148p.

BOURNE, A. E.; HAIGH, A. M.; ELLSWORTH, D. S. Stomatal sensitivity to vapour pressure deficit relates to climate of origin in Eucalyptus species. Tree Physiology, Oxford, v. 35, p. 266 - 278, 2015.

D'AMEN, M.; ZIMMERMANN. N. E.; PEARMAN, P. Conservation of phylogeographic lineages under climate change. Global Ecology and Biogeography, Nova Jersey, v. 22, p. 93 - 104, 2013.

ELITH, J.; PHILLIPS, S. J.; HASTIE, T.; DUDÍK, M.; CHEE, Y. E.; YATES, C. J.; A statistical explanation of MaxEnt for ecologists. Diversity and Distribution, Nova Jersey, v. 17, p. 43 - 57, 2011.

FERRER-SÁNCHEZ, Y.; RODRÍGUEZ-ESTRELLA, R. How rare species conservation management can be strengthened with the use of ecological niche modelling: the case for endangered endemic Gundlach's Hawk and Cuban Black-Hawk. Global Ecology and Conservation, Nova Jersey, v. 5, p. 88 - 99, 2016.

FLORESTA, Curitiba, PR, v. 48, n. 1, p. 77-86, jan./mar. 2018.

Lafetá. B. O. et al.

ISSN eletrônico 1982-4688

DOI: $10.5380 /$ rf.v48 i 150496 
GOLFARI, L.; CASER, R. L.; MOURA, V. P. G. Zoneamento ecológico esquemático para reflorestamento no Brasil (2 ${ }^{\mathbf{a}}$ aproximação). Belo Horizonte: Centro de Pesquisa Florestal da Região do Cerrado, 1978, 66p. (PNUD/FAO/IBDF/BRA - 45. Série Técnica, 11).

INMET - Instituto Nacional de Meteorologia. Disponível em: <http://www.inmet.gov.br> Acesso em: 17 de set. 2016.

JIANG, Y.; WANG, T.; BIE, C. A. J. M.; SKIDMORE, A. K.; LIU, X.; SONG, S.; ZHANG, L.; WANG, J.; SHAO, X. Satellite-derived vegetation indices contribute significantly to the prediction of epiphyllous liverworts. Ecological Indicators, Amsterdã, v. 38, p. 72 - 80, 2014.

JONKER, J. G. G.; JUNGINGER, H. M.; VERSTEGEN, J. A.; LIN, T.; RODRÍGUEZ, L. F.; TING, K. C.; FAAIJ, A. P. C.; van der HILST, F. Supply chain optimization of sugarcane first generation and eucalyptus second generation ethanol production in Brazil. Applied Energy, Amsterdã, v. 173, p. 494 - 510, 2016.

KUMAR, S.; STOHLGREN, T. J. Maxent modeling for predicting suitable habitat for threatened and endangered tree Canacomyrica monticule in New Caledonia. Journal of Ecology and Natural Environment, v. 1, n. 4, p. 94 - 98, 2009.

LAHUE, N. P.; BAÑOS, J. V.; ACEVEDO, P.; GORTÁZAR, C.; MARTÍNES-LOPEZ, B. Spatially explicit modeling of animal tuberculosis at the wildlife-liverstock interface in Ciudad Real province, Spain. Preventive Veterinary Medicine, Amsterdã, v. 128, p. 101 - 111, 2016.

MASUI, T.; MATSUMOTO, K.; HIJIOKA, Y.; KINOSHITA, T.; NOZAWA, T.; ISHIWATATU, S.; KATO, E.; SHUKLA, P. R.; YAMAGATA, Y.; KAINUMA, M. An emission pathway for stabilization at $6 \mathrm{Wm}^{-2}$ radiative forcing. Climatic Change, Amsterdã, v. 109, p. 59 - 76, 2011.

PHILLIPS, S. J.; ANDERSON, R. P.; SCHAPIRE, R. P. Maximum entropy modeling of species geographic distributions. Ecological Modelling, Amsterdã, v. 190, p. 231 - 259, 2006.

RIAHI, K.; RAO, S.; KREY, V.; CHO, C.; CHIRKOV, V.; FISCHER, G.; KINDERMANN, G.; NAKICENOVIC, N.; RAFAJ, P. RCP 8.5 A scenario of comparatively high greenhouse gas emissions. Climatic Change, Amsterdã, v. 109 , p. $33-57,2011$.

RÖDDER, D.; KIELGAST, J.; BIELBY, J.; SCHMIDTLEIN, S.; BOSCH, J.; GARNER, T. W. J.; VEITH, M.; WALKER, S.; FISCHER, M. C.; LÖTTERS, S. Global amphibian extinction risk assessment for the Panzootic Chytrid fungus. Diversity, Basel, v. 1, p. 52 - 66, 2009.

SANTOS, G. P.; ZANUNCIO, T. V.; VINHA, E.; ZANUNCIO, J. C. Influência de faixas de vegetação nativa em povoamentos de Eucalyptus cloeziana sobre população de Oxydia vesulia (Lepidoptera: Geometridae). Revista Árvore, Viçosa, v. 26, n. 4, p. 499 - 504, 2002.

SILVA, D. P.; GONZALEZ, V. H.; MELO, G. A. R.; LUCIA, M.; ALVAREZ, L. J.; MARCO JR., P. Seeking the flowers for the bees: integrating biotic interactions into niche models to assess the distribution of the exotic bee species Lithurgus huberi in South America. Ecological Modelling, Amsterdã, v. 273, p. 200 - 209, 2014.

SVENNING, J.; FLøJGAARD, C.; MARSKE, K. A.; NÓGUES-BRAVO, D. Applications of species distribution modelling to paleobiology. Quaternary Science Reviews, Amsterdã, v. 30, p. 2930 - 2947, 2011.

TAIZ, L.; ZEIGER, E. Fisiologia vegetal. Porto Alegre: Artmed, 3ed. 2004, 719p.

THOMSON, A. M.; CALVIN, K. V.; SMITH, S. J.; KYLE, G. P.; VOLKE, A.; PATEL, P.; DELGADO-ARIAS, S.; BOND-LAMBERTY, B.; WISE, M. A.; CLARKE, L. E.; EDMONDS, J. A. RCP4.5: a pathway for stabilization of radioative forcing by 2100. Climatic Change, Amsterdã, v. 109, p. 77 - 94, 2011.

TRUGuilho, P. F.; GOUlART, S. L.; ASSIS, C. O.; COUTO, F. B. S.; ALVES, I. C. N.; PROTÁSIO, T. P.; NAPOLI, A. Características de crescimento, composição química, física e estimativa de massa seca de madeira em clones e espécies de Eucalyptus jovens. Ciência Rural, Santa Maria, v. 45, n. 4, p. 661 - 666, 2015.

van VUUREN, D. P.; KRIEGLER, E.; O’NEILL, B. C.; EBI, K. L.; RIAHI, K.; CARTER, T. R.; EDMONDS, J.; HALLEGATTE, S.; KRAM, T.; MATHUR, R.; WINKLER, H. A new scenario framework for climate change research: scenario matrix architecture. Climatic Change, Amsterdã, v. 122, p. 373 - 386, 2014.

van VUUREN, D. P.; STEHFEST, E.; den ELZEN, M. G. J.; KRAM, T.; van VLIET, J.; DEETMAN, S.; ISAAC, M.; GOLDEWIJK, K. K.; HOF, A.; BELTRAN, A. M.; OOSTENRIJK, R.; van RUIJVEN, B. RCP2.6: exploring 
the possibility to keep global mean temperature increase below $2^{\circ} \mathrm{C}$. Climatic Change, Amsterdã, v. 109 , p. 95 116, 2011.

VESSELLA, F.; SCHIRONE, B. Predicting potential distribution of Quercus suber in Italy based on ecological niche models: conservation insights and reforestation involvements. Forest Ecology and Management, Amsterdã, v. 304, p. 150 - 161, 2013.

ZANUNCIO, J. C.; MEZZOMO, J. A.; GUEDES, R. N. C.; OLIVEIRA, A. C. Influence of strips of native vegetation on Lepidoptera associated with Eucalyptus cloeziana in Brazil. Forest Ecology and Management, Amsterdã, v. 108, p. 85-90, 1998.

FLORESTA, Curitiba, PR, v. 48, n. 1, p. 77-86, jan./mar. 2018

Lafetá. B. O. et al.

ISSN eletrônico 1982-4688

DOI: $10.5380 /$ rf.v48 i 150496 
FLORESTA, Curitiba, PR, v. 48, n. 1, p. 77-86, jan./mar.2018. Lafetá. B. O. etal. ISSN eletrônico 1982-4688 DOI: $10.5380 /$ rf.v48i1.50496 